Article

\title{
Effect of promoters on the selective hydrogenolysis of glycerol over $\mathrm{Pt} / \mathrm{W}$-containing catalysts
}

\author{
Jia Wang a,b,t, Nian Lei a,b,t, Chaojun Yang a,b, Yang Su a, Xiaochen Zhao a,*, Aiqin Wang a,\# \\ a State Key Laboratory of Catalysis, Dalian Institute of Chemical Physics, Chinese Academy of Sciences, Dalian 116023, Liaoning, China \\ b University of Chinese Academy of Sciences, Beijing 100049, China
}

\section{A R T I C L E I N F O}

\section{Article history:}

Received 5 April 2016

Accepted 26 May 2016

Published 5 September 2016

\section{Keywords:}

Glycerol

Hydrogenolysis

1,3-propanediol

Tungsten oxide

Promoter

\begin{abstract}
A B S T R A C T
Diverse promoters, including noble metals (such as $\mathrm{Ru}$, Ir and $\mathrm{Rh}$ ) and transition metal oxides (such as $\mathrm{Re}, \mathrm{La}, \mathrm{Fe}, \mathrm{Zr}, \mathrm{Sn}$ and Ce oxides) were introduced into $\mathrm{Pt} / \mathrm{WO}_{x}$ and $\mathrm{Pt} / \mathrm{WO}_{x} / \mathrm{Al}_{2} \mathrm{O}_{3}$ catalysts to investigate the ability of these promoters to modify activity and selectivity during glycerol hydrogenolysis to 1,3-propanediol. Among these, La exhibited the greatest promotional effect; the introduction of $0.1 \%$ La to the $\mathrm{Pt} / \mathrm{WO}_{x}$ improved activity, selectivity and stability, although the significant increase in selectivity came at the cost of a slight activity loss in the case of the $\mathrm{Pt} / \mathrm{WO}_{x} / \mathrm{Al}_{2} \mathrm{O}_{3}$ catalyst. Transmission electron microscopy, high angle annular dark field scanning tunneling electron microscopy and $\mathrm{NH}_{3}$-temperature programmed desorption all demonstrated that the introduction of La generates a greater quantity of acidic sites on the catalyst surface, and that the majority of the La species are associated with Pt particles. Most of the other additives resulted in only minimal improvements or even detrimental effects with regard to both activity and selectivity, although some appear to improve the stability of the catalyst.
\end{abstract}

(C) 2016, Dalian Institute of Chemical Physics, Chinese Academy of Sciences. Published by Elsevier B.V. All rights reserved.

\section{Introduction}

Advances in the biodiesel industry have resulted in the production of large amounts of glycerol as a byproduct of the transesterification of vegetable oils. Adding value to surplus glycerol by chemical transformations has attracted significant attention in recent decades [1]. Among the various transformation routes such as dehydration [2-4], oxidation [5,6], and reforming $[7,8]$, the selective hydrogenolysis of glycerol to 1,3-propanediol (1,3-PD) is highly desirable, owing to the widespread use of 1,3-PD in the polyester industry for the production of polytrimethylene terephthalate (PTT) $[9,10]$. Whereas the synthesis of 1,2-propanediol (1,2-PD) can be ac- complished with a wide range of catalysts, only Pt-W catalysts [11-13] and Ir-Re catalysts [14-16] can selectively cleave the secondary $-\mathrm{OH}$ group of the glycerol molecule to obtain high yields of 1,3-PD. Very recently, our group developed a novel Pt single/pseudo-single atom catalyst deposited on a mesoporous tungsten oxide [17]. The optimized interface between the Pt and the $\mathrm{WO}_{x}$, as well as the mesoporous structure of the material, result in outstanding activity by this catalyst under relatively low $\mathrm{H}_{2}$ pressures (i.e. $1 \mathrm{MPa}$ ), as well as a high space-time yield of 1,3-PD. Even under mild reaction conditions, however, the undesirable formation of 1-propanol as a result of over-hydrogenolysis is still the dominant reaction, with approximately $50 \%$ selectivity for this product. Therefore, there

\footnotetext{
* Corresponding author. Tel: +86-411-84379416; E-mail: zxc@dicp.ac.cn

\# Corresponding author. Tel: +86-411-84379348; Fax: +86-411-84685940; E-mail: aqwang@dicp.ac.cn

†These authors contributed equally to this work.

This work was supported by the National Natural Science Foundation of China $(21176235,21373206,21303187)$.

DOI: 10.1016/S1872-2067(16)62479-8 | http://www.sciencedirect.com/science/journal/18722067 | Chin. J. Catal., Vol. 37, No. 9, September 2016
} 
is a requirement to further enhance the selectivity for 1,3-PD by suppressing the formation of 1-propanol, and the addition of small amounts of promoters to the present $\mathrm{Pt} / \mathrm{WO}_{x}$ catalyst appears promising in this regard.

The introduction of a promoter is generally used to improve catalyst performance and stability via controlling and/or modulating the electronic structure of the noble metal [18], covering unfavorable sites [19], or modifying the surface chemistry of the support and its consequent interaction with the noble metal $[20,21]$. Because the selective hydrogenolysis of glycerol to 1,3-PD is a synergistic process based on concerted dehydration and hydrogenation, modification of the catalyst with a promoter could definitely tune both the catalytic performance and the distribution of products. Therefore, an investigation of promoter effects on Pt-W catalysts will be crucial to future breakthroughs in catalyst design. In previous studies, $\mathrm{AlO}_{x}$ promoters [22] and $\mathrm{Al}_{2} \mathrm{O}_{3}$ supports [11] have both demonstrated promising promotional effects during the selective hydrogenolysis of glycerol to 1,3-PD (90\% and 100\% glycerol conversions with $44 \%$ and $66 \%$ 1,3-PD selectivities, respectively). It is likely that the $\mathrm{AlO}_{x}$ support inhibits the over-hydrogenolysis reaction, although the mechanism is still unclear. Moreover, in contrast to $\mathrm{Pt} / \mathrm{WO}_{x}$, supported catalysts are more desirable in practical applications owing to their favorable mechanical and shaping properties. Despite this, positive promoters that work for $\mathrm{Pt} / \mathrm{WO}_{x}$ might not function with supported catalysts, because the different chemical properties of $\mathrm{Al}_{2} \mathrm{O}_{3}$ and $\mathrm{WO}_{x}$ may affect the action of the promoters. To examine such effects, the present work employed both Pt/WO and $\mathrm{Pt} / \mathrm{WO}_{x} / \mathrm{Al}_{2} \mathrm{O}_{3}$ as the mother catalysts, and introduced transition metal (such as $\mathrm{Re}, \mathrm{La}, \mathrm{Fe}, \mathrm{Zr}, \mathrm{Sn}$ and $\mathrm{Ce}$ ) oxides and noble metals (such as $\mathrm{Ru}$, Ir and $\mathrm{Rh}$ ) as promoters, and investigated the role of the promoters in modifying the hydrogenolysis reactivity. Among these catalysts, La and Fe showed positive promotional effects on $\mathrm{Pt} / \mathrm{WO}_{x}$, while Re showed a similar effect on Pt/ $\mathrm{WO}_{x} / \mathrm{Al}_{2} \mathrm{O}_{3}$.

\section{Experimental}

\subsection{Catalyst preparation}

\subsubsection{Preparation of a promoted $\mathrm{Pt} / W O_{x}$ catalyst}

The $\mathrm{Pt} / \mathrm{WO}_{x}$ was prepared according to a previously reported method [17]. Briefly, $3 \mathrm{~g}$ of $\mathrm{WCl}_{6}$ was added to $100 \mathrm{~mL}$ of ethanol with stirring at $500 \mathrm{r} / \mathrm{min}$ for $20 \mathrm{~min}$, and then transferred to a Teflon-lined autoclave and heated in an oven at $433 \mathrm{~K}$ for $36 \mathrm{~h}$. After cooling to room temperature, the solution was filtered and the recovered $\mathrm{WO}_{x}$ was washed with ethanol and water, then dried at $323 \mathrm{~K}$ for $6 \mathrm{~h}$ under vacuum. This material is denoted simply as $\mathrm{WO}_{x}$ herein. $\mathrm{Pt} / \mathrm{WO}_{x}$ was prepared by impregnating this material with an aqueous solution of $\mathrm{H}_{2} \mathrm{PtCl}_{6}$, followed by drying at $323 \mathrm{~K}$ for $6 \mathrm{~h}$ under vacuum.

Noble metal promoted catalysts were prepared by impregnating the $\mathrm{Pt} / \mathrm{WO}_{x}$ in $\mathrm{RhCl}_{3} \cdot 3 \mathrm{H}_{2} \mathrm{O}, \mathrm{RuCl}_{3} \cdot 3 \mathrm{H}_{2} \mathrm{O}$, or $\mathrm{H}_{2} \mathrm{IrCl}_{6}$ solutions overnight, with subsequent drying at $383 \mathrm{~K}$ for $12 \mathrm{~h}$. The as-prepared catalysts were calcined at $673 \mathrm{~K}$ for $1 \mathrm{~h}$ at a heating rate of $2 \mathrm{~K} / \mathrm{min}$.
Transition metal promoted catalysts were prepared using the incipient wetness impregnation method. The metal precursors used included $\mathrm{NH}_{4} \mathrm{ReO}_{4}, \mathrm{La}\left(\mathrm{NO}_{3}\right)_{3} \cdot 6 \mathrm{H}_{2} \mathrm{O}$, $\mathrm{Zr}\left(\mathrm{NO}_{3}\right)_{2} \cdot 5 \mathrm{H}_{2} \mathrm{O}, \mathrm{Al}\left(\mathrm{NO}_{3}\right)_{3} \cdot 9 \mathrm{H}_{2} \mathrm{O}, \mathrm{Fe}\left(\mathrm{NO}_{3}\right)_{3} \cdot 9 \mathrm{H}_{2} \mathrm{O}, \mathrm{Zn}\left(\mathrm{NO}_{3}\right)_{2} \cdot 6 \mathrm{H}_{2} \mathrm{O}$, $\mathrm{Ce}\left(\mathrm{NO}_{3}\right)_{3} \cdot 6 \mathrm{H}_{2} \mathrm{O}, \mathrm{SnCl}_{4} \cdot 5 \mathrm{H}_{2} \mathrm{O}, \mathrm{Ga}\left(\mathrm{NO}_{3}\right)_{3} \cdot 4.5 \mathrm{H}_{2} \mathrm{O}$, and ammonium paratungstate (APT). After impregnation, the samples were dried at $383 \mathrm{~K}$ for $12 \mathrm{~h}$ and then calcined at $673 \mathrm{~K}$ for $1 \mathrm{~h}$ at a heating rate of $2 \mathrm{~K} / \mathrm{min}$. These materials are denoted as $\mathrm{M} / \mathrm{Pt} / \mathrm{WO}_{\mathrm{x}}$. The M loading was fixed at $0.1 \mathrm{wt} \%$ and was calculated based on the mass of the mother catalyst. All the catalysts were reduced in $\mathrm{H}_{2}$ at $573 \mathrm{~K}$ prior to reaction trials.

\subsubsection{Preparation of the promoted Pt/WO $/ \mathrm{Ol}_{2} \mathrm{Al}_{2} \mathrm{O}_{3}$ catalyst}

The Pt/ $\mathrm{WO}_{x} / \mathrm{Al}_{2} \mathrm{O}_{3}$ catalyst was prepared using a sequential impregnation method. $\mathrm{WO}_{x} / \mathrm{Al}_{2} \mathrm{O}_{3}$ was initially synthesized according to a previously published procedure [11]. In this process, $1.248 \mathrm{~g}$ of APT was dissolved in distilled water at $363 \mathrm{~K}$. The solution was then cooled to room temperature, after which $10 \mathrm{~g}$ of $\mathrm{Al}_{2} \mathrm{O}_{3}$ was added, followed by additional stirring at room temperature for $16 \mathrm{~h}$. The solid was subsequently filtered off, dried at $383 \mathrm{~K}$ for $12 \mathrm{~h}$, and calcined at $1073 \mathrm{~K}$ for $3 \mathrm{~h}$ to obtain $\mathrm{WO}_{x} / \mathrm{Al}_{2} \mathrm{O}_{3}$. This material was then impregnated with an aqueous solution of $\mathrm{H}_{2} \mathrm{PtCl}_{6} \cdot 6 \mathrm{H}_{2} \mathrm{O}$, followed by drying at 383 $\mathrm{K}$ for $12 \mathrm{~h}$ and calcination at $573 \mathrm{~K}$ for $3 \mathrm{~h}$ to obtain the $\mathrm{Pt} / \mathrm{WO}_{x} / \mathrm{Al}_{2} \mathrm{O}_{3}$ catalyst. Analysis by inductively coupled plasma-atomic emission spectroscopy showed that the catalyst contained $7.0 \mathrm{wt} \%$ tungsten and $2.0 \mathrm{wt} \%$ platinum.

The introduction of promotors to the $\mathrm{Pt} / \mathrm{WO}_{x} / \mathrm{Al}_{2} \mathrm{O}_{3}$ catalyst was performed in a manner similar to that applied in the case of the Pt/WO $\mathrm{W}_{x}$ except for the use of a calcination temperature of $573 \mathrm{~K}$. The promoted catalysts are referred to herein as $\mathrm{M} / \mathrm{Pt} / \mathrm{WO}_{x} / \mathrm{Al}_{2} \mathrm{O}_{3}$, where the $\mathrm{M}$ loading was fixed at $0.1 \mathrm{wt} \%$ as calculated based on the mother catalyst.

For comparison purposes, $\mathrm{M}-\mathrm{Pt} / \mathrm{WO}_{x} / \mathrm{Al}_{2} \mathrm{O}_{3}$ catalysts were also prepared by co-impregnation of $\mathrm{WO}_{x} / \mathrm{Al}_{2} \mathrm{O}_{3}$ using a solution of $\mathrm{H}_{2} \mathrm{PtCl}_{6} \cdot 6 \mathrm{H}_{2} \mathrm{O}$ and the corresponding metal precursor. The resulting solids were dried at $383 \mathrm{~K}$ and calcined at $573 \mathrm{~K}$ for $3 \mathrm{~h}$. In addition, $\mathrm{Pt} / \mathrm{M} / \mathrm{WO}_{x} / \mathrm{Al}_{2} \mathrm{O}_{3}$ catalysts were prepared by sequential incipient wetness impregnation of $\mathrm{WO}_{x} / \mathrm{Al}_{2} \mathrm{O}_{3}$ with solutions of the corresponding metal precursor and $\mathrm{H}_{2} \mathrm{PtCl}_{6} \cdot 6 \mathrm{H}_{2} \mathrm{O}$.

The $\mathrm{WO}_{x} / \mathrm{Pt} / \mathrm{Al}_{2} \mathrm{O}_{3}$ catalyst was prepared via a sequential impregnation method. The initial $\mathrm{Pt} / \mathrm{Al}_{2} \mathrm{O}_{3}$ catalyst was prepared by impregnation of $\mathrm{Al}_{2} \mathrm{O}_{3}$ samples with an aqueous solution of $\mathrm{H}_{2} \mathrm{PtCl}_{6} \cdot 6 \mathrm{H}_{2} \mathrm{O}$, after which the impregnated sample was dried at $383 \mathrm{~K}$ for $12 \mathrm{~h}$ and subsequently calcined at $673 \mathrm{~K}$ for 3 h. $\mathrm{WO}_{x} / \mathrm{Pt} / \mathrm{Al}_{2} \mathrm{O}_{3}$ was prepared by impregnation of $\mathrm{Pt} / \mathrm{Al}_{2} \mathrm{O}_{3}$ samples with an aqueous solution of ammonium metatungstate (AMT). Impregnated samples were dried at $383 \mathrm{~K}$ for $12 \mathrm{~h}$ and subsequently calcined at $823 \mathrm{~K}$ for $3 \mathrm{~h}$. The platinum content was fixed at $2 \mathrm{wt} \%$, while the tungsten content was varied between (0.1 and 8) wt\%.

\subsection{Catalytic reactions and product analysis}

Glycerol hydrogenolysis trials over $\mathrm{Pt} / \mathrm{WO}_{x}$ were conducted in a 75-mL autoclave with a Teflon lining. Typically, $0.3 \mathrm{~g}$ of 
catalyst and $12 \mathrm{~g}$ of an aqueous glycerol solution (5 wt\%) were transferred into the autoclave, after which the chamber was flushed several times with $\mathrm{H}_{2}$ and then filled with $\mathrm{H}_{2}$ to a pressure of 1.0 MPa. The reactor was subsequently sealed and heated to $413 \mathrm{~K}$ and the reaction proceeded at a stirring speed of $800 \mathrm{r} / \mathrm{min}$ for $12 \mathrm{~h}$. The same conditions were applied in the performance tests over $\mathrm{Pt} / \mathrm{WO}_{x} / \mathrm{Al}_{2} \mathrm{O}_{3}$, except using a $3 \mathrm{wt} \%$ glycerol solution, an initial $\mathrm{H}_{2}$ pressure of $5.0 \mathrm{MPa}$ and a reaction temperature of $453 \mathrm{~K}$.

After each reaction, the gaseous and liquid products were collected separately. The liquid phase products were analyzed with an Agilent 7890B gas chromatograph with an HP-INNOWAX capillary column $(30 \mathrm{~m} \times 0.32 \mathrm{~mm} \times 0.5 \mu \mathrm{m}$, flame ionization detector) using $n$-butanol as the internal standard, while the gaseous products were analyzed online using the same instrument with a HayeSep Q packed column (3 $\mathrm{m} \times 1 / 8$ ", thermal conductivity detector). The conversion of glycerol and the selectivity for each liquid product were calculated using the following equations.

Conversion of glycerol $(\%)=$ (moles of glycerol consumed) $/$ (moles of glycerol initially added) $\times 100$.

Selectivity $(\%)=$ (moles of carbon in a given prod$\mathrm{uct}) /($ moles of carbon in glycerol consumed $) \times 100$

Deactivation rate $\left(\% \mathrm{~h}^{-1}\right)=($ Conv.max - Conv.final $) \times 100 /(t \times$ Conv.max)

\subsection{Catalyst characterization}

High resolution transmission electron microscopy (HRTEM) and high angle annular dark field scanning tunneling electron microscopy (HAADF-STEM) images were obtained on a JEM-2100F instrument operating at $200 \mathrm{kV}$. The samples were prepared by ultrasonically dispersing the finely powdered catalysts in ethanol and the dropping each solution onto a $\mathrm{C} / \mathrm{Cu}$ TEM grid.

$\mathrm{NH}_{3}$-adsorption data were obtained using a Micromeritics AutoChem II 2920 chemisorber to measure the acidity of catalysts. The samples were degassed in He flow at $393 \mathrm{~K}$ for $1 \mathrm{~h}$ and then cooled to $373 \mathrm{~K}$ prior to pulse adsorption trials. After adsorption saturation, the amount of $\mathrm{NH}_{3}$ adsorption was calculated accordingly.

$\mathrm{H}_{2}$ adsorption trials were conducted with the same instrument to measure the $\mathrm{H}_{2}$ uptake of catalysts. The samples were reduced in $\mathrm{H}_{2}$ flow at $573 \mathrm{~K}$ for $1 \mathrm{~h}$ after being degassed in $\mathrm{Ar}$ flow at $583 \mathrm{~K}$ for $30 \mathrm{~min}$, then cooled to $323 \mathrm{~K}$ in preparation for pulsed adsorption. After adsorption saturation, the amount of $\mathrm{H}_{2}$ adsorption was calculated accordingly.

\section{Results and discussion}

\subsection{The effects of transition metal promoters}

As noted, transition metal promoters can drastically change the activity and selectivity of noble metal supported catalysts. Thus the effects of transition metal promoters during the hydrogenolysis of glycerol were examined in the present work, with the results shown in Table 1 . In the case of $\mathrm{Pt} / \mathrm{WO}_{x}$, the additions of Re, Sn, Zn, and Ga (Entries 5-8) decreased glycerol conversion but increased 1,3-PD selectivity, while Zr (Entry 4) had the opposite effect. During the sequential glycerol hydrogenolysis reaction, it is usually difficult to simultaneously enhance both glycerol conversion and selectivity for 1,3-PD, because a highly active catalyst often generates over-hydrogenolysis, thus decreasing the selectivity, and vice versa. However, when promoted by La or Fe (Entries 2 and 3), the glycerol conversion was increased from $37.4 \%$ to $39.9 \%$ or $41.6 \%$, respectively, while the 1,3-PD selectivity was improved from $35.1 \%$ to $41.3 \%$ or $37.8 \%$. These slight enhancements resulted in a higher yield of 1,3-PD compared with that obtained with $\mathrm{Pt} / \mathrm{WO}_{x}$. Moreover, the incorporation of La obviously improved the stability of the mother catalyst. The $0.1 \mathrm{La} / \mathrm{Pt} / \mathrm{WO}_{x}$ had an average $0.13 \%$ activity loss per hour during an 85-h stability test (Fig. 1), while the activity loss of the $\mathrm{Pt} / \mathrm{WO}_{x}$ was $0.33 \%$ per hour over a 70 -h stability test [17]. In the case of the $\mathrm{Pt} / \mathrm{WO}_{x} / \mathrm{Al}_{2} \mathrm{O}_{3}$, the addition of $\mathrm{La}$ or $\mathrm{Fe}$ also

Table 1

Results obtained with transition metal promoters on Pt-W catalysts during the hydrogenolysis of glycerol.

\begin{tabular}{|c|c|c|c|c|c|c|c|c|}
\hline \multirow{2}{*}{ Entry } & \multirow{2}{*}{ Catalyst } & \multirow{2}{*}{$\begin{array}{c}\text { Conv. } \\
(\%)\end{array}$} & \multicolumn{5}{|c|}{ Selectivity (\%) } & \multirow{2}{*}{$\begin{array}{c}\text { Yield } \\
(\%)\end{array}$} \\
\hline & & & 2-PO & 1-PO & 1,2-PD & 1,3-PD & Others $^{\text {a }}$ & \\
\hline 1 & $\mathrm{Pt} / \mathrm{WO}_{x}$ & 37.4 & 5.1 & 50.3 & 2.3 & 35.1 & 7.2 & 13.1 \\
\hline 2 & $0.1 \mathrm{La} / \mathrm{Pt} / \mathrm{WO}_{x}$ & 39.9 & 4.80 & 44.7 & 2.8 & 41.3 & 6.4 & 16.5 \\
\hline 3 & $0.1 \mathrm{Fe} / \mathrm{Pt} / \mathrm{WO}_{x}$ & 41.6 & 6.1 & 50.5 & 2.4 & 37.8 & 3.2 & 15.8 \\
\hline 4 & $0.1 \mathrm{Zr} / \mathrm{Pt} / \mathrm{WO}_{x}$ & 40.2 & 5.7 & 46.9 & 4.5 & 33.3 & 9.6 & 13.4 \\
\hline 5 & $0.1 \mathrm{Re} / \mathrm{Pt} / \mathrm{WO}_{x}$ & 18.1 & 5.2 & 46.1 & 4.0 & 38.4 & 6.3 & 7.0 \\
\hline 6 & $0.1 \mathrm{Sn} / \mathrm{Pt} / \mathrm{WO}_{x}$ & 29.8 & 5.8 & 40.8 & 8.5 & 39.6 & 5.3 & 11.8 \\
\hline 7 & $0.1 \mathrm{Zn} / \mathrm{Pt} / \mathrm{WO}_{x}$ & 16.2 & 4.7 & 40.0 & 6.3 & 44.2 & 4.8 & 7.2 \\
\hline 8 & $0.1 \mathrm{Ga} / \mathrm{Pt} / \mathrm{WO}_{x}$ & 25.0 & 6.1 & 44.0 & 6.1 & 36.5 & 7.3 & 9.1 \\
\hline 9 & $0.1 \mathrm{Ce} / \mathrm{Pt} / \mathrm{WO}_{x}$ & 4.0 & 6.6 & 54.4 & 4.8 & 24.6 & 9.6 & 1.0 \\
\hline 10 & $\mathrm{Pt} / \mathrm{WO}_{x} / \mathrm{Al}_{2} \mathrm{O}_{3}$ & 65.4 & 7.4 & 23.2 & 7.2 & 48.2 & 14.0 & 31.5 \\
\hline 11 & $0.1 \mathrm{La} / \mathrm{Pt} / \mathrm{WO}_{x} / \mathrm{Al}_{2} \mathrm{O}_{3}$ & 47.4 & 9.5 & 24.1 & 12.5 & 56.9 & 1.3 & 27.0 \\
\hline 12 & $0.1 \mathrm{Fe} / \mathrm{Pt} / \mathrm{WO}_{x} / \mathrm{Al}_{2} \mathrm{O}_{3}$ & 38.3 & 6.2 & 21.8 & 12.2 & 57.0 & 2.8 & 21.8 \\
\hline 13 & $0.1 \mathrm{Zr} / \mathrm{Pt} / \mathrm{WO}_{x} / \mathrm{Al}_{2} \mathrm{O}_{3}$ & 55.9 & 7.1 & 26.4 & 5.8 & 49.1 & 11.6 & 27.4 \\
\hline 14 & $0.1 \mathrm{Re} / \mathrm{Pt} / \mathrm{WO}_{x} / \mathrm{Al}_{2} \mathrm{O}_{3}$ & 67.9 & 10.6 & 29.6 & 8.7 & 49.0 & 2.1 & 33.3 \\
\hline 15 & $0.1 \mathrm{Sn} / \mathrm{Pt} / \mathrm{WO}_{x} / \mathrm{Al}_{2} \mathrm{O}_{3}$ & 21.0 & 9.7 & 32.4 & 16.0 & 32.6 & 9.3 & 6.8 \\
\hline 16 & $0.1 \mathrm{Ce} / \mathrm{Pt} / \mathrm{WO}_{x} / \mathrm{Al}_{2} \mathrm{O}_{3}$ & 32.7 & 9.4 & 16.5 & 19.2 & 51.5 & 3.4 & 16.8 \\
\hline
\end{tabular}

a This category included propane, ethylene glycol, ethanol, methanol, methane and ethane. 


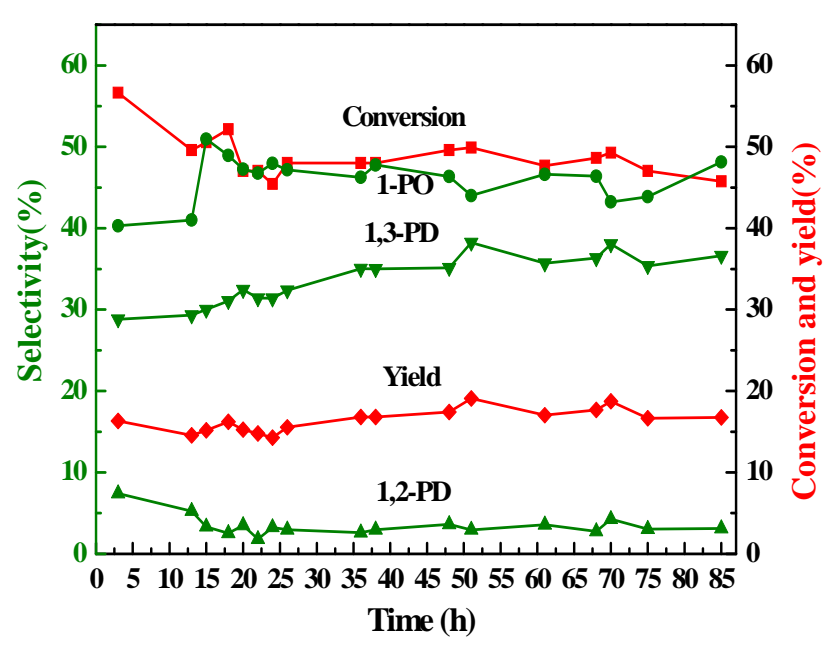

Fig. 1. Stability of $0.1 \mathrm{La} / \mathrm{Pt} / \mathrm{WO}_{x}$ over time. Conditions: fixed-bed reactor at $413 \mathrm{~K}, 1.0 \mathrm{MPa}$, gas hourly space velocity of $1000 \mathrm{~h}^{-1}$, liquid hourly space velocity of $1 \mathrm{~h}^{-1}, 5 \mathrm{wt} \%$ glycerol.

remarkably enhanced the 1,3-PD selectivity (from $48.2 \%$ to $57.0 \%)$ although the glycerol conversion decreased to some extent. We assume that the inherently higher activity of the $\mathrm{Pt} / \mathrm{WO}_{x} / \mathrm{Al}_{2} \mathrm{O}_{3}$ was responsible for the lesser extent of activity enhancement on adding the promoters. It should be noted that improved selectivity at the cost of a slight loss of activity is the most acceptable scenario with regard to practical applications. In this regard, La is the better promoter.

To illustrate the effects of promoters on hydrogenolysis performance with or without the $\mathrm{Al}_{2} \mathrm{O}_{3}$ support, further investigations were performed, using La as a model promoter.

In principle, hydrogenolysis requires acidic sites for dehydration and metallic sites for hydrogenation, and the selective hydrogenolysis of glycerol to 1,3-PD involves the concerted functioning of these two types of sites. For this reason, the acidity of a catalyst is widely accepted as playing a crucial role in

\section{Table 2}

Textural parameters and acid properties of La-promoted catalysts and reference catalysts.

\begin{tabular}{lccc}
\hline Catalyst & $\begin{array}{c}\text { Acid content } \\
(\mathrm{mmol} / \mathrm{g})\end{array}$ & $\begin{array}{c}\mathrm{BET} \\
\left(\mathrm{m}^{2} / \mathrm{g}\right)\end{array}$ & $\begin{array}{c}D_{\mathrm{p}} \\
(\mathrm{nm})\end{array}$ \\
\hline $\mathrm{Pt} / \mathrm{WO}_{x}$ & 0.65 & 82 & 6.5 \\
$0.1 \mathrm{La} / \mathrm{Pt} / \mathrm{WO}_{x}$ & 0.86 & 62 & 5.0 \\
$\mathrm{Pt} / \mathrm{WO}{ }_{x} / \mathrm{Al}_{2} \mathrm{O}_{3}$ & 0.40 & 105 & 9.0 \\
$0.1 \mathrm{La} / \mathrm{Pt} / \mathrm{WO}_{x} / \mathrm{Al}_{2} \mathrm{O}_{3}$ & 0.50 & 101 & 9.3 \\
\hline
\end{tabular}

glycerol conversion and product selectivity [23, 24]. According to the $\mathrm{NH}_{3}$ adsorption results (Table 2), the addition of La did indeed generate a greater quantity of acidic sites on both the $0.1 \mathrm{La} / \mathrm{Pt} / \mathrm{WO}_{x}$ and $0.1 \mathrm{La} / \mathrm{Pt} / \mathrm{WO}_{x} / \mathrm{Al}_{2} \mathrm{O}_{3}$. In addition to these surface acid sites, as determined by $\mathrm{NH}_{3}$ adsorption, we propose that acid sites could also have originated from Brønsted acid sites generated in situ by the heterolytic dissociation of $\mathrm{H}_{2}$ on metal sites with subsequent spillover to the support [17]. In addition to the increased acid site concentration, the Brunauer-Emmett-Teller (BET) surface area and pore structure of the original $\mathrm{Pt} / \mathrm{WO}_{x}$ were both greatly decreased after the introduction of La, possibly due to partial collapse of the mesoporous $\mathrm{WO}_{x}$ structure during calcination. In the case of the $\mathrm{Pt} / \mathrm{WO}_{x} / \mathrm{Al}_{2} \mathrm{O}_{3}$, however, the BET surface area and pore structure were almost unchanged after La introduction, indicating the superior mechanical strength of the $\mathrm{Al}_{2} \mathrm{O}_{3}$ support compared to the $\mathrm{WO}_{x}$.

TEM and HAADF-STEM images demonstrated aggregations of Pt single/pseudo-single atoms after La introduction (Fig. 2), which may have been caused by the high temperature calcination following impregnation. In contrast, EDS results showed that Pt species were only partially aggregated, and that there were still a large number of single/pseudo-single Pt atoms highly dispersed on the $\mathrm{W}$ species. In addition, the majority of the La species were found to be associated with Pt species, in

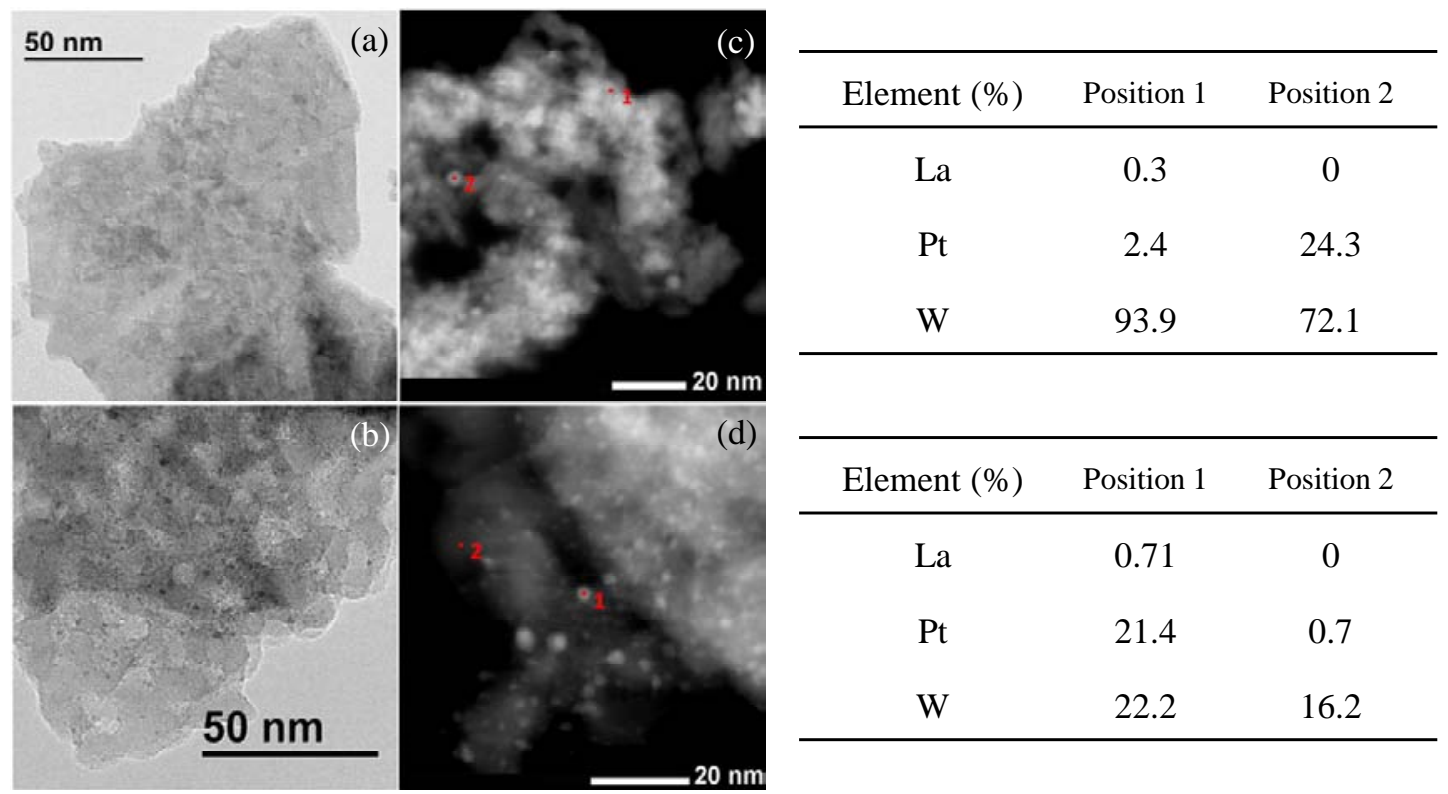

Fig. 2. TEM images of (a) $0.1 \mathrm{La} / \mathrm{Pt} / \mathrm{WO}_{x}$ and (b) $0.1 \mathrm{La} / \mathrm{Pt} / \mathrm{WO}_{x} / \mathrm{Al}_{2} \mathrm{O}_{3}$, and $\mathrm{HAADF} \mathrm{STEM}$ images of (c) $0.1 \mathrm{La} / \mathrm{Pt} / \mathrm{WO} \mathrm{O}_{x}$ and (d) $0.1 \mathrm{La} / \mathrm{Pt} / \mathrm{WO} \mathrm{O}_{x} / \mathrm{Al}_{2} \mathrm{O}_{3}$. The tables present STEM-EDS elemental analysis data for positions 1 and 2. 
accordance with the deposition sequence of each component.

It has been reported that La possesses unique properties for catalytic cellulose conversion [25]. In the present study, La also exhibited a superior promotional effect for Pt-W catalysts during the selective hydrogenolysis of glycerol to 1,3-PD, thus it was thought that optimization of the La content might provide opportunities to further improve the hydrogenolysis performance. However, additional evaluation (Table 3) demonstrated that the use of a greater quantity of La both lowered glycerol conversion and decreased 1,3-PD selectivity, likely due to over-coverage of the active Pt sites by La species. Further investigation of the deposition sequence of La relative to Pt on the $\mathrm{WO}_{x} / \mathrm{Al}_{2} \mathrm{O}_{3}$ sample showed that La must be introduced after Pt loading, otherwise the activity is greatly decreased upon introduction of the La. This result suggests that the coverage of the highly active Pt sites by a very small amount of La tends to enhance selectivity without much activity loss.

\subsection{The effects of noble metal promoters}

$\mathrm{Ru}$, Ir, and $\mathrm{Rh}$ were introduced to $\mathrm{Pt} / \mathrm{WO}_{x}$ and $\mathrm{Pt} / \mathrm{WO}_{x} / \mathrm{Al}_{2} \mathrm{O}_{3}$ with a loading of $0.1 \mathrm{wt} \%$, respectively, and the promotional effects were examined during the hydrogenolysis of glycerol under optimized reaction conditions (Table 4). In the case of the $\mathrm{Pt} / \mathrm{WO}_{x}$, the $\mathrm{Ru}$ promoted material showed similar performance to the mother catalyst (Entry 2), while Ir and Rh promoters significantly decreased the glycerol conversion (from $37.4 \%$ to approximately $26.3 \%$ ) but maintained the 1,3-PD selectivity at approximately $35.0 \%$ (Entries 3 and 4). Similarly, no obvious effect was identified when using the
$\mathrm{Ru} / \mathrm{Pt} / \mathrm{WO}_{x} / \mathrm{Al}_{2} \mathrm{O}_{3}$, indicating that $\mathrm{Ru}$ has the same function with and without a support. In contrast, the negative effect of $\mathrm{Rh}$ was eliminated when employing $\mathrm{Al}_{2} \mathrm{O}_{3}$ as the support, and the yield of 1,3-PD returned to $32.4 \%$. In addition, introducing Ir to the $\mathrm{Pt} / \mathrm{WO}_{x} / \mathrm{Al}_{2} \mathrm{O}_{3}$ decreased not only the glycerol conversion but also the 1,3-PD selectivity, indicating the negative effects were more pronounced on supported catalysts. Chemical adsorption results demonstrated that variation in the initial acid amounts over the $\mathrm{Al}_{2} \mathrm{O}_{3}$ supported catalysts (from 0.40 to $0.39 \mathrm{mmol} / \mathrm{g}$ ) was less than that over the $\mathrm{Pt} / \mathrm{WO}_{x}$ (from 0.65 to $0.55 \mathrm{mmol} / \mathrm{g}$ ) after Ir introduction, suggesting that the hydrogenolysis reactivity is not highly correlated with the initial acid amount. As well, compared with the transition metal promoted catalysts, that decreased the $\mathrm{H}_{2}$ uptake from 0.067 to the range of 0.046 to $0.049 \mathrm{mmol} / \mathrm{g}$, the use of Ir greatly decreased the $\mathrm{H}_{2}$ uptake, from 0.067 to $0.024 \mathrm{mmol} / \mathrm{g}$. This effect most likely was responsible for the inferior performance of this catalyst during the hydrogenolysis of glycerol to 1,3-PD.

Electron microscopy (Fig. 3) shows significant aggregation of Pt on the Pt/ $\mathrm{WO}_{x}$ after Ir introduction, consistent with the $\mathrm{H}_{2}$ adsorption results, and presumably responsible for the low activity of this material during the hydrogenolysis reaction. The Pt particle sizes were maintained over the supported catalysts, indicating that the presence of an $\mathrm{Al}_{2} \mathrm{O}_{3}$ support may facilitate the stabilization of these particles. Taking the chemical $\mathrm{H}_{2}$ adsorption results into account, the significant decrease in the $\mathrm{H}_{2}$ uptake over the Ir promoted $\mathrm{Pt} / \mathrm{WO}_{x} / \mathrm{Al}_{2} \mathrm{O}_{3}$ is attributed to the change in electronic structure, rather than particle size, of the active Pt species, which greatly influenced the performance of this material during the selective hydrogenolysis of glycerol.

Table 3

The effects of La on Pt-W catalysts during hydrogenolysis of glycerol.

\begin{tabular}{|c|c|c|c|c|c|c|c|c|}
\hline \multirow{2}{*}{ Entry } & \multirow{2}{*}{ Catalyst } & \multirow{2}{*}{$\begin{array}{c}\text { Conv. } \\
(\%)\end{array}$} & \multicolumn{5}{|c|}{ Selectivity ( \% ) } & \multirow{2}{*}{$\begin{array}{c}\text { Yield } \\
(\%)\end{array}$} \\
\hline & & & 2-PO & 1-P0 & 1,2-PD & 1,3-PD & Others ${ }^{a}$ & \\
\hline 1 & $\mathrm{Pt} / \mathrm{WO}_{x}$ & 37.4 & 5.1 & 50.3 & 2.3 & 35.1 & 7.2 & 13.1 \\
\hline 2 & $0.1 \mathrm{La} / \mathrm{Pt} / \mathrm{WO}_{x}$ & 39.9 & 4.8 & 44.7 & 2.8 & 41.3 & 6.4 & 16.5 \\
\hline 3 & $0.2 \mathrm{LaPt} / \mathrm{WO}_{x}$ & 28.6 & 5.9 & 45.2 & 5.7 & 38.5 & 4.7 & 11.0 \\
\hline 4 & $0.4 \mathrm{LaPt} / \mathrm{WO}_{x}$ & 17.0 & 5.9 & 47.1 & 4.1 & 37.3 & 5.6 & 6.3 \\
\hline 5 & $0.5 \mathrm{LaPt} / \mathrm{WO}_{x}$ & 14.8 & 6.1 & 45.4 & 4.0 & 37.7 & 6.8 & 5.6 \\
\hline 6 & $\mathrm{Pt} / \mathrm{WO}_{x} / \mathrm{Al}_{2} \mathrm{O}_{3}$ & 65.4 & 7.4 & 23.2 & 7.2 & 48.2 & 14.0 & 31.5 \\
\hline 7 & $0.1 \mathrm{La} / \mathrm{Pt} / \mathrm{WO}_{x} / \mathrm{Al}_{2} \mathrm{O}_{3}$ & 47.4 & 9.5 & 24.1 & 12.5 & 56.9 & 1.3 & 27.0 \\
\hline 8 & $\mathrm{Pt} / 0.1 \mathrm{La} / \mathrm{WO}_{x} / \mathrm{Al}_{2} \mathrm{O}_{3}$ & 37.5 & 4.2 & 12.2 & 14.0 & 51.1 & 18.5 & 19.2 \\
\hline 9 & Pt-0.1La/ $\mathrm{WO}_{x} / \mathrm{Al}_{2} \mathrm{O}_{3}$ & 32.9 & 7.3 & 17.2 & 14.9 & 50.0 & 10.6 & 16.4 \\
\hline
\end{tabular}

a This category included propane, ethylene glycol, ethanol, methanol, methane and ethane.

Table 4

The effects of noble metal promoters on Pt-W catalysts during hydrogenolysis of glycerol.

\begin{tabular}{|c|c|c|c|c|c|c|c|c|}
\hline \multirow{2}{*}{ Entry } & \multirow{2}{*}{ Catalyst } & \multirow{2}{*}{$\begin{array}{c}\text { Conv. } \\
(\%)\end{array}$} & \multicolumn{5}{|c|}{ Selectivity ( \% ) } & \multirow{2}{*}{$\begin{array}{c}\text { Yield } \\
(\%)\end{array}$} \\
\hline & & & $2-\mathrm{PO}$ & 1-P0 & 1,2-PD & 1,3-PD & Others $^{\text {a }}$ & \\
\hline 1 & $\mathrm{Pt} / \mathrm{WO}_{x}$ & 37.4 & 5.1 & 50.3 & 2.3 & 35.1 & 7.2 & 13.1 \\
\hline 2 & $0.1 \mathrm{Ru} / \mathrm{Pt} / \mathrm{WO}_{x}$ & 33.6 & 5.1 & 49.9 & 2.6 & 35.5 & 6.9 & 12.0 \\
\hline 3 & $0.1 \mathrm{Ir} / \mathrm{Pt} / \mathrm{WO}_{x}$ & 25.6 & 5.6 & 53.0 & 4.5 & 34.4 & 2.5 & 8.8 \\
\hline 4 & $0.1 \mathrm{Rh} / \mathrm{Pt} / \mathrm{WO}_{x}$ & 26.3 & 5.9 & 50.2 & 4.0 & 33.1 & 6.8 & 8.7 \\
\hline 5 & $\mathrm{Pt} / \mathrm{WO}_{x} / \mathrm{Al}_{2} \mathrm{O}_{3}$ & 65.4 & 7.4 & 23.2 & 7.2 & 48.2 & 14.0 & 31.5 \\
\hline 6 & $0.1 \mathrm{Ru} / \mathrm{Pt} / \mathrm{WO}_{x} / \mathrm{Al}_{2} \mathrm{O}_{3}$ & 58.1 & 7.7 & 26.2 & 9.2 & 50.0 & 6.9 & 29.1 \\
\hline 7 & $0.1 \mathrm{Ir} / \mathrm{Pt} / \mathrm{WO}_{x} / \mathrm{Al}_{2} \mathrm{O}_{3}$ & 55.7 & 6.4 & 33.1 & 6.1 & 41.1 & 13.3 & 22.9 \\
\hline 8 & $0.1 \mathrm{Rh} / \mathrm{Pt} / \mathrm{WO}_{x} / \mathrm{Al}_{2} \mathrm{O}_{3}$ & 67.7 & 5.2 & 19.8 & 9.3 & 47.8 & 17.9 & 32.4 \\
\hline
\end{tabular}

a This category included propane, ethylene glycol, ethanol, methanol, methane and ethane. 


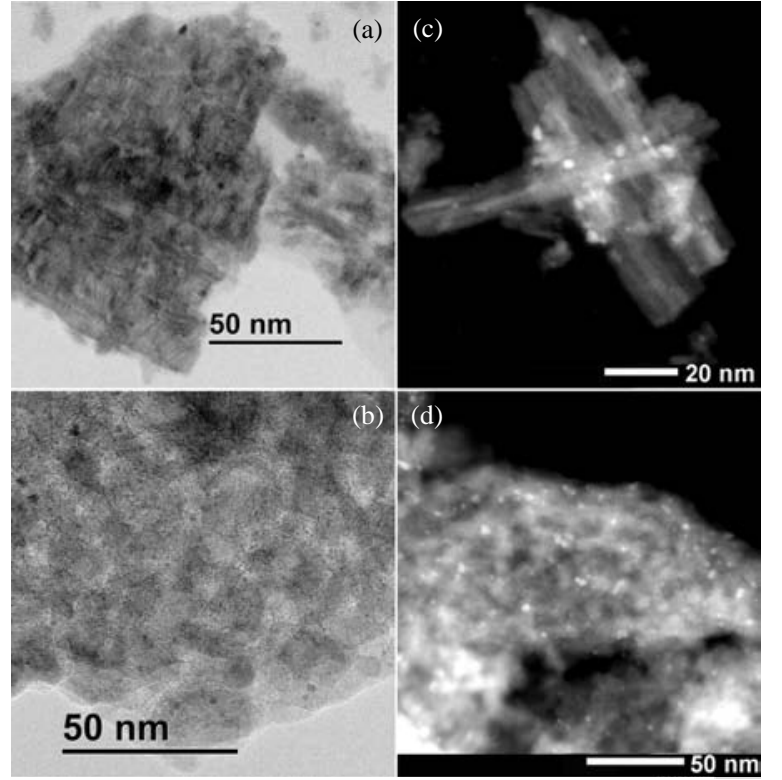

Fig. 3. TEM images of (a) $0.1 \mathrm{Ir} / \mathrm{Pt} / \mathrm{WO}_{x}$ and (b) $0.1 \mathrm{Ir} / \mathrm{Pt} / \mathrm{WO}_{x} / \mathrm{Al}_{2} \mathrm{O}_{3}$, and HAADF-STEM images of (c) $0.1 \mathrm{Ir} / \mathrm{Pt} / \mathrm{WO}_{x}$ and (d) $0.1 \mathrm{Ir} / \mathrm{Pt} / \mathrm{WO}_{x} /$ $\mathrm{Al}_{2} \mathrm{O}_{3}$.

\subsection{The effect of impregnation sequence}

Previous studies have demonstrated that the addition sequence of the $\mathrm{AlO}_{x}$ promoter strongly influences the hydrogenolysis reactivity and the product selectivities [22]. Therefore, taking $\mathrm{Pt} / \mathrm{WO}_{x}$ and $\mathrm{Pt} / \mathrm{WO}_{x} / \mathrm{Al}_{2} \mathrm{O}_{3}$ as reference catalysts, the effects of varying the $\mathrm{Al}$ and $\mathrm{W}$ impregnation sequence were investigated (Table 5). The introduction of either $\mathrm{W}$ or $\mathrm{Al}$ species to the $\mathrm{Pt} / \mathrm{WO}_{x}$ resulted in lower reactivity (glycerol conversion decreased from $37.4 \%$ to $27.1 \%$ or $17.0 \%$, respectively), owing to the coverage of active sites, while no significant improvements were identified in the selectivity for 1,3-PD. Similar effects were observed when introducing $\mathrm{W}$ to the $\mathrm{Pt} / \mathrm{WO}_{x} / \mathrm{Al}_{2} \mathrm{O}_{3}$ catalyst. These results imply that merely covering the active Pt sites by other species cannot enhance the selectivity for 1,3-PD, although it does decrease the glycerol conversion. To probe the interactions between $\mathrm{Pt}$ and $\mathrm{WO}_{x}$, we deposited a small amount of $\mathrm{WO}_{x}$ species on the $\mathrm{Pt} / \mathrm{Al}_{2} \mathrm{O}_{3}$ mother catalyst (Entries 6 and 7). In this case, the predominant product from glycerol hydrogenolysis was 1,2-PD rather than 1,3-PD. However, further increasing the amount of $\mathrm{WO}_{x}$ (Entries 8 and 9) led to more 1,3-PD and less 1,2-PD, akin to the results obtained from a typical $\mathrm{Pt} / \mathrm{WO}_{x} / \mathrm{Al}_{2} \mathrm{O}_{3}$ catalyst. These results strongly suggest that the interface between the $\mathrm{Pt}$ and $\mathrm{WO}_{x}$ determines the selective hydrogenolysis of glycerol to give 1,3-PD, irrespective of their deposition sequence. Therefore, future work may focus on the design of more selective catalysts by maximizing the $\mathrm{Pt} / \mathrm{WO}_{x}$ interface.

\section{Conclusion}

In summary, a diverse range of promoters, including transition and noble metals, was introduced to $\mathrm{Pt} / \mathrm{WO}_{x}$ and $\mathrm{Pt} / \mathrm{WO}_{x} / \mathrm{Al}_{2} \mathrm{O}_{3}$. La was the most effective promoter, and the introduction of $0.1 \%$ La improved catalytic activity and selectivity for 1,3-PD, as well as the stability of $\mathrm{Pt} / \mathrm{WO}_{x}$. However, the significant increase in 1,3-PD selectivity came at the cost of a slight activity loss in the case of the $\mathrm{Pt} / \mathrm{WO}_{x} / \mathrm{Al}_{2} \mathrm{O}_{3}$. In some instances, the same promoter exhibited different effects with or without an $\mathrm{Al}_{2} \mathrm{O}_{3}$ support. Fe promoted $\mathrm{Pt} / \mathrm{WO}_{x}$ and Re promoted Pt/ $\mathrm{WO}_{x} / \mathrm{Al}_{2} \mathrm{O}_{3}$ both demonstrated superior 1,3-PD productivity relative to the unpromoted catalysts, while the opposite effect was observed when varying the mother catalysts. In addition, some other promoted catalysts, such as $\mathrm{Zr}$ and $\mathrm{Sn}$ promoted $\mathrm{Pt} / \mathrm{WO}_{x}$ and $\mathrm{Fe}$ and $\mathrm{Zr}$ promoted $\mathrm{Pt} / \mathrm{WO}_{x} / \mathrm{Al}_{2} \mathrm{O}_{3}$, showed slightly decreased production of $1,3-\mathrm{PD}$ but still have significant potential in practical applications. This is because the introduction of promoters sometimes enhances the stability of the catalysts, which might be even more significant than the reactivity itself. Characterization of selected catalysts implied that the promotion mechanism likely results from modifying the electronic structure of the active Pt species. Hydrogenolysis performance is not highly correlated with original acid amounts, and therefore measurements of acidic sites generated in situ will be of great importance in future work to provide insight into the reaction mechanism and allow the rational design of such catalysts.

\section{References}

[1] T. Mizugaki, R. Arundhathi, T. Mitsudome, K. Jitsukawa, K. Kaneda, ACS Sustain. Chem. Eng., 2014, 2, 574-578.

Table 5

The effect of impregnation sequence and $\mathrm{WO}_{x}$ amount on hydrogenolysis of glycerol over Pt-W catalysts.

\begin{tabular}{|c|c|c|c|c|c|c|c|c|}
\hline \multirow{2}{*}{ Entry } & \multirow{2}{*}{ Catalyst } & \multirow{2}{*}{$\begin{array}{c}\text { Conv. } \\
(\%)\end{array}$} & \multicolumn{5}{|c|}{ Selectivity (\%) } & \multirow{2}{*}{$\begin{array}{c}\text { Yield } \\
(\%) \\
\end{array}$} \\
\hline & & & $2-\mathrm{PO}$ & 1-PO & 1,2-PD & 1,3-PD & Others ${ }^{a}$ & \\
\hline 1 & $\mathrm{Pt} / \mathrm{WO}_{x}$ & 37.4 & 5.1 & 50.3 & 2.3 & 35.1 & 7.2 & 13.1 \\
\hline 2 & $0.1 \mathrm{~W} / \mathrm{Pt} / \mathrm{WO}_{x}$ & 27.1 & 5.6 & 46.2 & 8.0 & 30.0 & 10.2 & 8.2 \\
\hline 3 & $0.1 \mathrm{Al} / \mathrm{Pt} / \mathrm{WO}_{x}$ & 17.0 & 5.5 & 45.9 & 4.7 & 35.5 & 8.4 & 6.1 \\
\hline 4 & $\mathrm{Pt} / \mathrm{WO}_{x} / \mathrm{Al}_{2} \mathrm{O}_{3}$ & 65.4 & 7.4 & 23.2 & 7.2 & 48.2 & 14.0 & 31.5 \\
\hline 5 & $0.1 \mathrm{~W} / \mathrm{Pt} / \mathrm{WO}_{x} / \mathrm{Al}_{2} \mathrm{O}_{3}$ & 44.1 & 8.2 & 24.1 & 10.0 & 47.1 & 10.6 & 20.8 \\
\hline 6 & $0.5 \mathrm{~W} / \mathrm{Pt} / \mathrm{Al}_{2} \mathrm{O}_{3}$ & 5.4 & 1.8 & 5.9 & 68.9 & 3.0 & 20.4 & 0.2 \\
\hline 7 & $1 \mathrm{~W} / \mathrm{Pt} / \mathrm{Al}_{2} \mathrm{O}_{3}$ & 6.5 & 2.5 & 9.9 & 56.0 & 2.8 & 28.8 & 0.2 \\
\hline 8 & $4 \mathrm{~W} / \mathrm{Pt} / \mathrm{Al}_{2} \mathrm{O}_{3}$ & 10.1 & 4.7 & 12.9 & 32.6 & 34.8 & 15.0 & 3.5 \\
\hline 9 & $8 \mathrm{~W} / \mathrm{Pt} / \mathrm{Al}_{2} \mathrm{O}_{3}$ & 8.7 & 7.5 & 16.6 & 17.5 & 43.9 & 14.5 & 3.8 \\
\hline
\end{tabular}

a This category included propane, ethylene glycol, ethanol, methanol, methane and ethane. 


\section{Graphical Abstract}

Chin. J. Catal., 2016, 37: 1513-1520 doi: 10.1016/S1872-2067(16)62479-8

Effect of promoters on the selective hydrogenolysis of glycerol over Pt/W-containing catalysts

Jia Wang, Nian Lei, Chaojun Yang, Yang Su, Xiaochen Zhao*,

Aiqin Wang*

Dalian Institute of Chemical Physics, Chinese Academy of Sciences

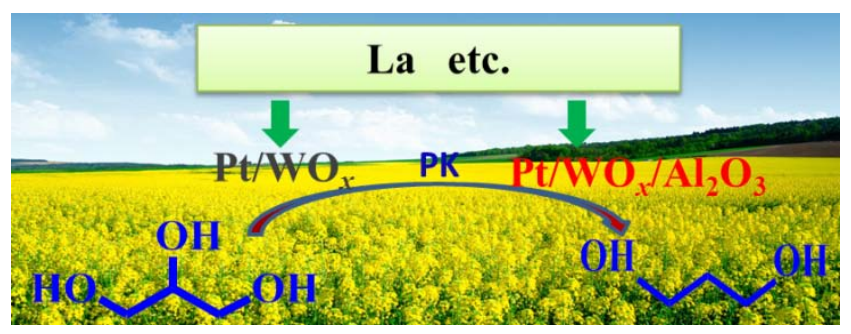

Different promoters were introduced to $\mathrm{Pt} / \mathrm{WO}_{x}$ and $\mathrm{Pt} / \mathrm{WO}_{x} / \mathrm{Al}_{2} \mathrm{O}_{3}$ catalysts for the selective hydrogenolysis of glycerol to 1,3-propanediol. The effects of these promoters on the hydrogenolysis performance and product selectivity were investigated and detailed comparisons were made both with and without $\mathrm{Al}_{2} \mathrm{O}_{3}$ supports.

[2] B. Katryniok, S. Paul, F. Dumeignil, ACS Catal., 2013, 3, 1819-1834.

[3] P. Lauriol-Garbay, J. M. M. Millet, S. Loridant, V. Bellière-Baca, P. Rey, J. Catal., 2011, 280, 68-76.

[4] L. L. Ning, Y. J. Ding, W. M. Chen, L. F. Gong, R. H. Lin, Y. Lü, Q. Xin, Chin. J. Catal., 2008, 29, 212-214.

[5] J. Gao, D. Liang, P. Chen, Z. Y. Hou, X. M. Zheng, Catal. Lett., 2009, 130, 185-191.

[6] M. Lo Faro, M. Minutoli, G. Monforte, V. Antonucci, A. S. Aricò, Biomass Bioenergy, 2011, 35, 1075-1084.

[7] S. Authayanun, A. Arpornwichanop, Y. Patcharavorachot, W. Wiyaratn, S. Assabumrungrat, Int. J. Hydrogen Energy, 2011, 36, 267-275.

[8] P. D. Vaidya, A. E. Rodrigues, Chem. Eng. Technol., 2009, 32, 1463-1469.

[9] Y. Nakagawa, M. Tamura, K. Tomishige, J. Mater. Chem. A, 2014, 2, 6688-6702.

[10] Y. L. Wang, J. X. Zhou, X. W. Guo, RSC Adv., 2015, 5, 74611-74628.

[11] R. Arundhathi, T. Mizugaki, T. Mitsudome, K. Jitsukawa, K. Kaneda, ChemSusChem, 2013, 6, 1345-1347.

[12] L. F. Gong, Y. Lü, Y. J. Ding, R. H. Lin, J. W. Li, W. D. Dong, T. Wang, W. M. Chen, Chin. J. Catal., 2009, 30, 1189-1191.

[13] L. J. Liu, Y. H. Zhang, A. Q. Wang, T. Zhang, Chin. J. Catal., 2012, 33,
$1257-1261$.

[14] Y. Amada, Y. Shinmi, S. Koso, T. Kubota, Y. Nakagawa, K. Tomishige, Appl. Catal. B, 2011, 105, 117-127.

[15] C. H. Deng, L. Leng, J. H. Zhou, X. G. Zhou, W. K. Yuan, Chin. J. Catal., 2015, 36, 1750-1758.

[16] J. Guan, X. F. Chen, G. M. Peng, X. C. Wang, Q. Cao, Z. G. Lan, X. D. Mu, Chin. J. Catal., 2013, 34, 1656-1666.

[17] J. Wang, X. C. Zhao, N. Lei, L. Li, L. L. Zhang, S. T. Xu, S. Miao, X. L. Pan, A. Q. Wang, T. Zhang, ChemSusChem, 2016, 9, 784-790.

[18] D. L. Li, Y. Nakagawa, K. Tomishige, Appl. Catal. A, 2011, 408, 1-24.

[19] J. K. A. Clarke, Chem. Rev., 2002, 11, 41-70.

[20] Y. Amada, S. Koso, Y. Nakagawa, K. Tomishige, MRS Proceedings, 2011, 1326.

[21] Y. Amada, H. Watanabe, M. Tamura, Y. Nakagawa, K. Okumura, K. Tomishige, J. Phy. Chem. C, 2012, 116, 23503-23514.

[22] T. Mizugaki, T. Yamakawa, R. Arundhathi, T. Mitsudome, K. Jitsukawa, K. Kaneda, Chem. Lett., 2012, 41, 1720-1722.

[23] S. H. Zhu, X. Q. Gao, Y. L. Zhu, J. L. Cui, H. Y. Zheng, Y. W. Li, Appl. Catal. B, 2014, 158-159, 391-399.

[24] L. Z. Qin, M. J. Song, C. L. Chen, Green Chem., 2010, 12, 1466-1472.

[25] R. Y. Sun, T. T. Wang, M. Y. Zheng, W. Q. Deng, J. F. Pang, A. Q. Wang, X. D. Wang, T. Zhang, ACS Catal., 2015, 5, 874-883.

\section{助剂对铂-铇催化剂体系催化氢解甘油制 1,3-丙二醇性能的影响

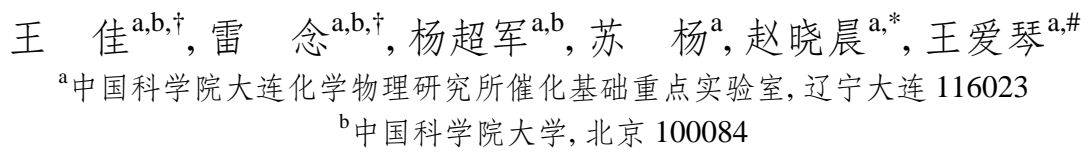

摘要: 甘油作为生物柴油产业的副产物大量过剩, 通过甘油氢解制备具有高附加值的丙二醇既符合原子经济的原则, 又具 有重要的学术意义和应用价值. 尤其是选择氢解制得 1,3-丙二醇, 因其产物在新型聚酯材料合成中不可替代的作用而备受 关注, 被认为是最具工业应用潜力的甘油转化工艺之一. 目前, 可高选择性制得 1,3-丙二醇的催化剂体系主要是为铱-铼催 化剂和铂-铇催化剂两类. 前期工作表明, 氧化铇担载的铂单原子/准单原子催化剂 $\left(\mathrm{Pt} / \mathrm{WO}_{x}\right)$ 具有优异的低压活性 $(1 \mathrm{MPa}$ 氢气) 和 1,3-丙二醇时空收率. 然而在该温和条件下, 催化产物仍然以过度氢解的产物正丙醇为主. 一般来讲, 引入助剂可 以通过改变活性组分的电子结构、覆盖不利反应位点、调变载体表面化学性质等来改变催化剂的催化活性、选择性和稳 
定性. 我们以单原子/准单原子催化剂 $\mathrm{Pt} / \mathrm{WO}_{x}$ 和担载型催化剂 $\mathrm{Pt} / \mathrm{WO}_{x} / \mathrm{Al}_{2} \mathrm{O}_{3}$ 为催化剂母体, 引入过渡金属和贵金属助剂, 考察助剂对氢解反应活性和选择性的影响, 并对比有无氧化铝载体时助剂对反应活性的影响.

对于 $\mathrm{Pt} / \mathrm{WO}_{x}$ 体系, $\mathrm{La}$ 和 $\mathrm{Fe}$ 的引入有助于甘油转化率和 1, 3-丙二醇选择性的提高, 同时也明显地提高了催化剂的稳定 性. 其中 $0.1 \% \mathrm{La}$ 是最佳引入量. 然而, 对于担载型催化剂 $\mathrm{Pt} / \mathrm{WO}_{x} / \mathrm{Al}_{2} \mathrm{O}_{3}$, $\mathrm{La}$ 的引入在提高 1,3 -丙二醇选择性的同时, 甘油 的转化率也有一定程度下降. 但由于 $\mathrm{Pt} / \mathrm{WO}_{x} / \mathrm{Al}_{2} \mathrm{O}_{3}$ 催化剂的本征活性较高, 通过加入助剂提高 1,3 -丙二醇的选择性在实 际应用中更为重要. 表征分析表明, 无论对于 $\mathrm{Pt} / \mathrm{WO}_{x}$ 还是 $\mathrm{Pt} / \mathrm{WO}_{x} / \mathrm{Al}_{2} \mathrm{O}_{3}$ 催化剂, 大部分的 $\mathrm{La}$ 都在 $\mathrm{Pt}$ 颗粒上; 同时 $\mathrm{La}$ 的 引入提高了催化剂的酸量.

在贵金属助剂中, $\mathrm{Ru}, \mathrm{Ir}$ 改性的 $\mathrm{Pt} / \mathrm{WO}_{x}$ 和 $\mathrm{Pt} / \mathrm{WO}_{x} / \mathrm{Al}_{2} \mathrm{O}_{3}$ 催化剂上, 1,3-丙二醇的收率均有所降低, $\mathrm{Ru}$ 助剂的降低幅度 较小. 相反, 助剂 $\mathrm{Rh}$ 对 $\mathrm{Pt} / \mathrm{WO}_{x}$ 和 $\mathrm{Pt} / \mathrm{WO}_{x} / \mathrm{Al}_{2} \mathrm{O}_{3}$ 催化剂上反应性能的影响截然不同: $\mathrm{Rh} / \mathrm{P} \mathrm{t} / \mathrm{WO}_{x}$ 催化剂上 1,3 -丙二醇的收 率从 $13.1 \%$ 降到 $8.7 \%, \mathrm{Rh} / \mathrm{Pt} / \mathrm{WO}_{x} / \mathrm{Al}_{2} \mathrm{O}_{3}$ 的 1,3-丙二醇收率从 $31.5 \%$ 略升到 $32.4 \%$.

另外, 由于前期研究表明助剂铝的担载顺序对催化活性有重要影响, 因此我们对铂、铇、铝的担载顺序进行了考察. 研 究表明, 在活性组分铂上担载铝或铇物种对催化活性有一定程度的抑制; 催化剂体系中铇的含量直接影响甘油的转化率 和产物的选择性; 含量过少时, 甘油转化率极低并以 1,2-丙二醇为主要产物.

虽然大部分助剂对铂-铇催化剂体系没有明显的促进作用, 但是助剂的添加通常可以抑制活性组分的烧结、提高催化剂 的稳定性; 因此, 我们篮选出的 La, Fe, Re, Ru, Rh 等助剂仍具有深入研究的价值和工业应用的潜力.

关键词: 甘油; 氢解; 1,3 -丙二醇; 氧化铇; 助剂

收稿日期: 2016-04-05. 接受日期: 2016-05-26. 出版日期: 2016-09-05.

*通讯联系人. 电话: (0411)84379416; 电子信箱: zxc@dicp.ac.cn

通讯联系人. 电话: (0411)84379348; 传真: (0411)84685940; 电子信箱: aqwang@dicp.ac.cn

†共同第一作者.

基金来源：国家自然科学基金 (21176235, 21373206, 21303187).

本文的英文电子版由Elsevier出版社在ScienceDirect上出版(http://www.sciencedirect.com/science/journal/18722067). 